\title{
POTENSI AIR TANAH PASCA GEMPA TEKTONIK DI LERENG MERAPI DAERAH KLATEN JAWA TENGAH
}

\author{
Suharjo, Alif Noor Anna, \\ Retno Woro Kaeksi, dan Yuli Priyana \\ Fakultas Geografi Universitas Muhammadiyah Surakarta \\ Jl. A. Yani Pabelan Kartasura Tromol Pos I Surakarta 57102, Telp. (0271) 717417 \\ Psw. 151-153, Fax. (0271) 7155448 \\ E-mail:suharjo@ums.ac.id; anna@ums.ac.id; \\ retno@ums.ac.id; yuli_priyana@ums.ac.id
}

\begin{abstract}
She purpose of this research is to analyze the potency of land water in the post tectonic earchquake at Merapi slope in Klaten regency, Central Java. This research applies a survey method. The result of analysis is made based on the trilinier diagram, Stiff pattern, and the quality standard of drinking water. The collected data are in the form of land form, shallow land water data, suppressed land water, and well or spring. The results of the sesearch show that 1) the land form in Klaten is divided into four sets of landform, they are peake and slope of volcano, feet of volcano, fluvial palin under volcano, and a set of structural morphology. 2) the potency of land water can be tested based on the amount of land water and the quality of land water. The amount of land water in Klaten regency 260,502,274 $\mathrm{m}^{3} /$ year or 727,618,722 liter/day. The amount of land water above is taken from free land water 73,301,436 $\mathrm{m}^{3} /$ year, suppressed land water 34,138,520 $\mathrm{m}^{3} /$ year, and land water taken from well or spring 153,062,784 $\mathrm{m}^{3} /$ year. The quality of shallow land water in Klaten regency is proper to consume. 3) The distribution of upland water potency happens in the feet volcano land form, the potency of medium land water happens in the superficial of fluvial under volcano land form, and the potency of lowland water happens in the slope volcano land form and in the structural range of hills at Bayat subdistrict, 4) The tectonic earthquake gives serious effect toward morphological changes, land split, land subsident and the potency of land water in the fluvial plain of land form under volcano and structural range of hills in the area of Bayat subdistrict, and 5) In 2008, the needs of drinking water in Klaten regency is predicted around 1,164,000 people $\times 150$ liter/day $=174,600,000$ liter/day.
\end{abstract}

Keywords: potency of land water, tectonic earthquake and land form.

\section{PENDAHULUAN}

Undang-Undang No. 7 tahun 2004 tentang sumber daya air yang belum diikuti peraturan pemerintah maka yang terjadi di lapangan: 1) Pengelolaan dan pembagian air dari mata air daerah kabupaten Klaten nampaknya belum adanya koordinasi antar masyarakat pengguna, masyarakat dengan kepala daerah, serta antar kepala daerah sebagai pengguna air tanah dari Gunung Api Merapi (Kabupaten Klaten, Sukoharjo dan Kabupa- ten Kota Surakarta), 2) belum adanya kesepakatan bersama yang dituangkan dalam Peraturan Daerah (Perda) tentang pengelolaan air tanah di lereng Merapi, yang meliputi daerah (Klaten, Sukoharjo, Surakarta).

Sumber air tanah di daerah Klaten terdiri dari air tanah bebas, air tanah tertekan dan air tanah dari mata air atau spring. Jumlah mata air di daerah klaten sebanyak 162 dengan rincian 28 mata air sudah mati dan 134 mata air mempunyai debit air bervariasi (Suharjo, 2005). 
Potensi air tanah bebas dan air tanah tertekan dipengaruhi oleh relief, jenis batuan, struktur batuan. Gempa bumi tektonik yang terjadi pada tanggal $27 \mathrm{Mei}$ 2006 daerah Klaten berakibat terjadi degradasi lahan (rekahan, retakan, longsor lahan, sembulan, dan amblesan) terjadi di bentuklahan dataran fluvial bawah volkan Merapi dan bentuklahan asal struktural perbukitan Bayat (Suharjo, 2006). Berubahnya relief dan kedudukan struktur batuan berpengaruh terhadap potensi air tanah dangkal dan air tanah dalam di daerah Klaten. Sehingga data dasar air tanah sebelum gempa bumi tektonik pada tanggal 27 Mei 2006 mengalami perubahan di perlu diperbaiki.

Tujuan yang dicapai dalam penelitian analisis analisis potensi air tanah di setiap bentuklahan pasca gempa bumi tektonik 27 Mei 2006.

Manfaat yang diharapkan dalam penelitian, untuk perbaikan data dasat air tanah pasca gempa bumi tektonik; pengembangan materi ajar geomorfologi terapan.

\section{METODE PENELITIAN}

Penelitian dilakukan di daerah Kabupaten Klaten Jawa Tengah dengan medode survai, sedang analisi datanya dilakukan di Fakultas Geografi Universitas Muhammadiyah Surakarta dan Laboratorium Fakultas geografi Universitas Gadjah Mada Yogyakarta; analisis hasil digunakan metode deskriptif.

Alat dan bahan yang digunakan dalam penelitian yaitu : (a) Peta rupa bumi daerah Klaten Skala 1 : 25000, (b) Peta geologi lembar Yogyakarta dan Surakarta skala 1: 100.000, (c) peta geologi cekungan air tanah Karanganyar- Boyolali, (d) peta morfologi cekungan air tanah Karanganyar-Boyolali, (e) peta kontur muka air tanah di Cekungan air tanah Karanganyar-Boyolali, (f) botol dan plastik sampel air tanah (g) unsur kimia untuk analisa laboratorium, (h) Komputer dan seperangkat analisa GIS, (i) alat alat tulis.

Analisi potensi air tanah dilakukan di setiap bentuklahan di daerah Kabupaten Klaten. Penyusunan bentuklahan didasarkan aspek morfologi, proses geomorfologi dan kondisi litologi daerah klaten.

\section{HASIL DAN PEMBAHASAN}

\section{Bentuklahan}

Bentuklahan dibedakan menjadi : a). Lereng dan puncak volkan, b). Kaki volkan, c). Dataran fluvial bawah volkan, dan d). Bentuklahan asal struktural perbukitan Bayat ( lihat gambar 1)

\section{Curah Hujan}

Curah hujan di daerah klaten berkisar antara 1500 - $3000 \mathrm{~mm} /$ tahun (berdasarkan data pemetaan sumberdaya alam). Lebih lanjut berdasarkan curah hujan, secara garis besar Kabupaten Klaten dapat dibedakan dalam 3 wilayah, yaitu:

1. Wilayah curah hujan $1500-2000 \mathrm{~mm} /$ tahun merupakan kriteria beriklim lembab yang tergantung pada lamanya musim hujan dengan 3-4 bulan kering, meliputi daerah Kecamatan Gantiwarno, Wedi, Cawas, Trucuk, Kalikotes, dan Kebonarum.

2. Wilayah curah hujan 2000-2500 mm/ tahun, merupakan kriteria beriklim sangat lembab dengan 3-4 bulan kering meliputi daerah Prambanan, Bayat, Manisrenggo, Ceper, Wonosari, Delanggu, Polanharjo, Jatinom, Ngawen, 


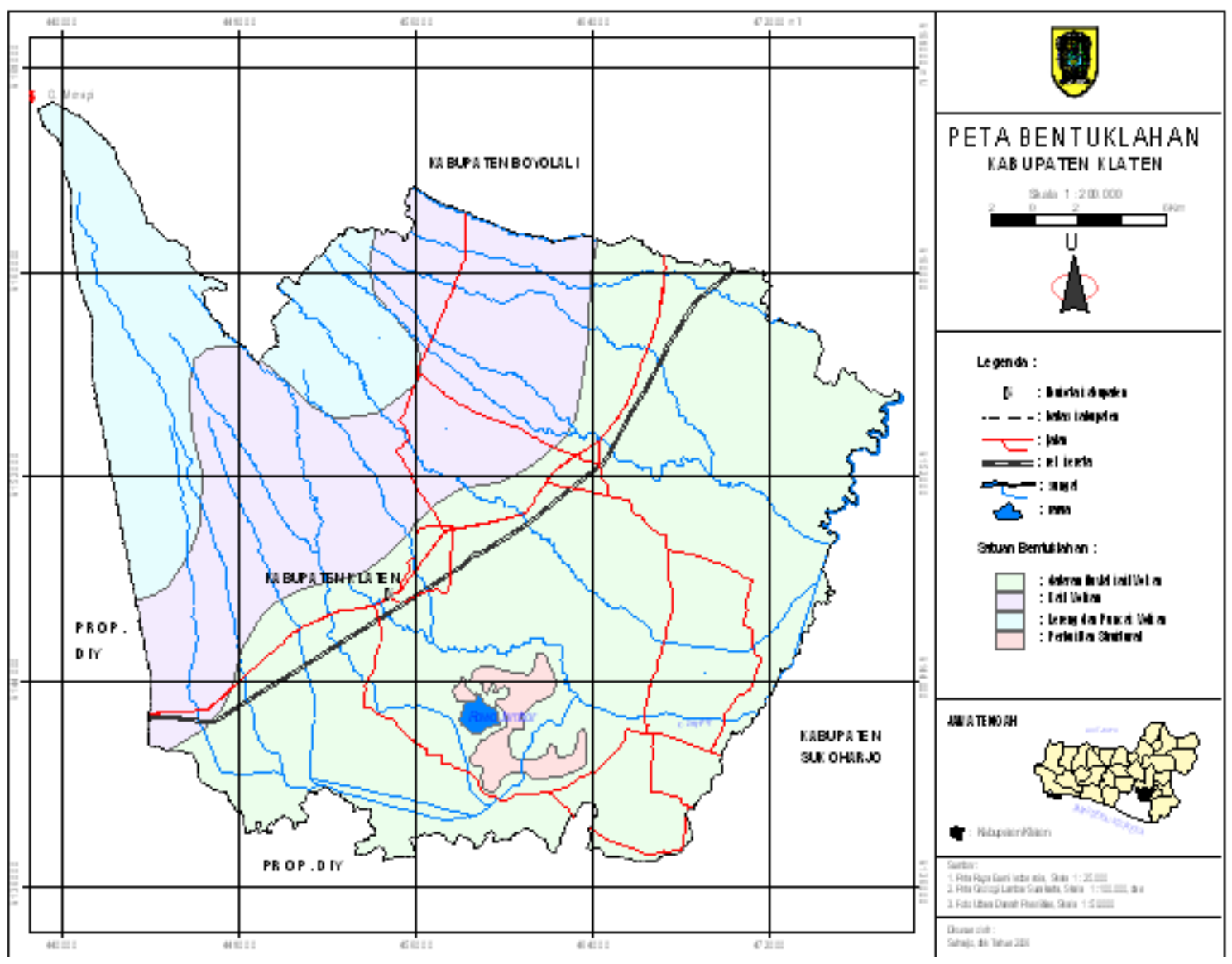

Sumber : Suharjo, 2006

Gambar 1. Peta Bentuklahan Daerah Klaten Jawa Tengah

Pedan, Karangdowo, Juwiring, Karanganom, Tulung, Kemalang, Klaten Tengah, Klaten Selatan, dan Klaten Utara.

3. Wilayah curah hujan $2500-3000 \mathrm{~mm} /$ tahun, yang merupakan kriteria beriklim basah dengan 2-3 bulan kering, meliputi daerah Jogonalan dan Kecamatan Karangnongko.

Air hujan disamping meresap ke dalam perlapisan batuan membentuk air tanah, sebagian mengalir melalui sungai di wilayah Klaten. Sungai-sungai di wilayah Klaten sebagian besar mengalirkan air sepanjang tahun dan air tersebut sebagian besar dipergunakan untuk irigasi. Berdasarkan data dari Sub Dinas Pengairan DPU Kabupaten Klaten volume air sungai tersebut kurang lebih $1.083 .198 .528 \mathrm{~m}^{3}$.

\section{Air Tanah}

Di daerah Klaten, air tanah dibedakan menjadi a). Air tanah Bebas, b). Air tanah tertekan dan c). Air tanah dari mata air atau spring. Data air tanah bebas dan air tanah tertekan didapatkan dari Dinas Pertambangan Dan Energi Porpinsi Jawa dan dianalisa menggunakan Sistem Informasi Geografi ( SIG). Penyebaran sampel air tanah bebas dan air tanah tertekan dapat dilihat pada Gambar 2. 


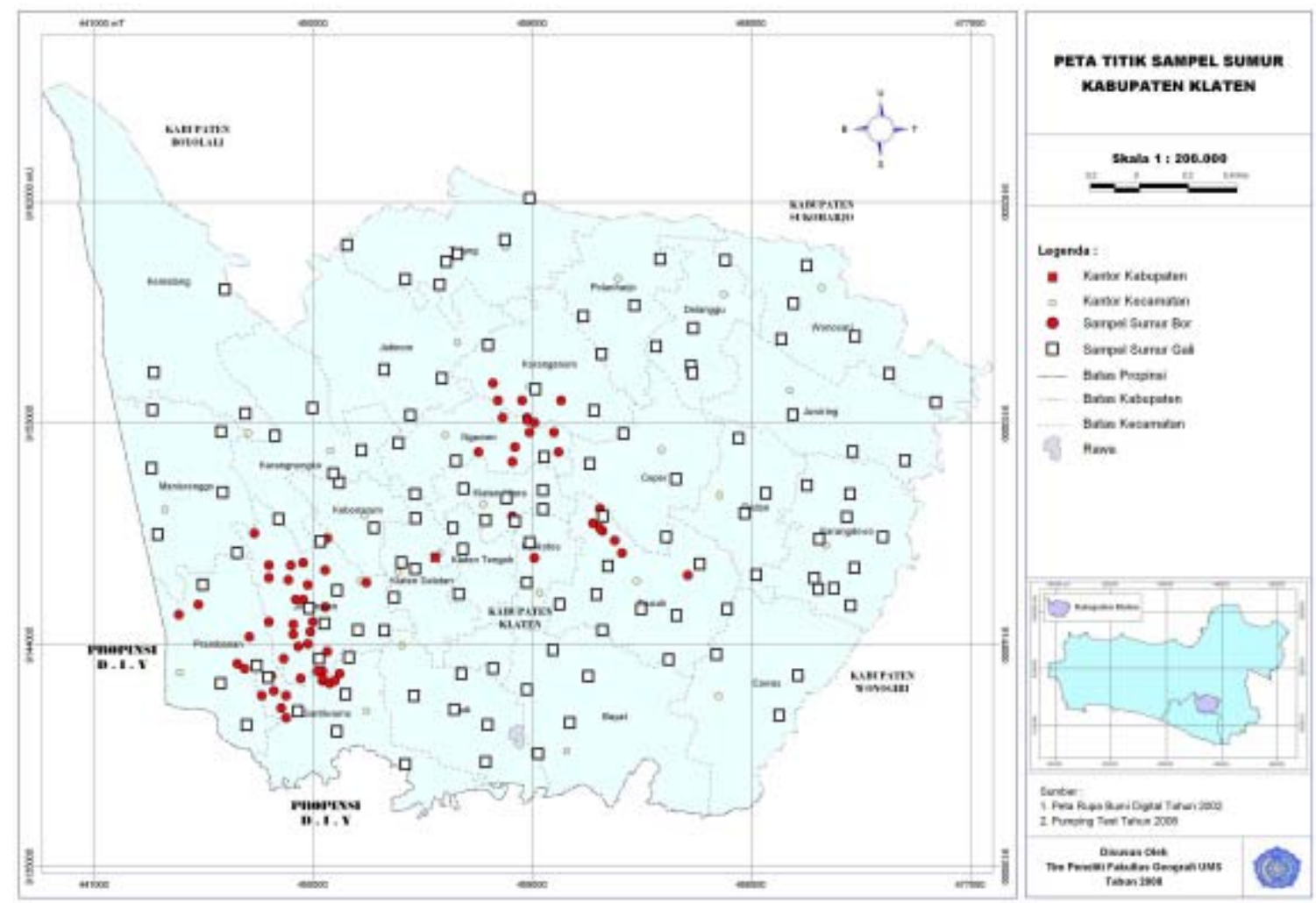

Sumber: 1. Dinas Pertambangan Dan Energi Propinsi Jawa'Tengah , 2 dan analisa GIS.

Gambar 2. Peta Data Air Tanah Bebas dan air tanah Tertekan

\section{Air Tanah Bebas}

Airtanah (Groundwater) adalah air yang terdapat dalam ruang antar butir (pori) batuan atau tanah yang terdapat dalam bawah permukaan tanah dan terletak pada zone jenuh (Todd, 1980). Airtanah yang dimaksudkan disini adalah air tanah bebas, yaitu airtanah pada bagian atas dibatasi oleh muka preatik dan pada bagian bawah dibatasi oleh lapisan kedap air.

Debit air tanah bebas dihitung berdasarkan rumus $\mathrm{Q}=\mathrm{TxIxL}$ (Walton, 1970), dimana $\mathrm{Q}=$ debit air tanah ( $\mathrm{m} 3 /$ tahun $)$; $\mathrm{T}=$ koefisien transmisibilitas, $\mathrm{I}=$ gradien hidrolik dan $\mathrm{L}=$ rata rata lebar aquifer. Untuk mendapatkan besarnya koefisien transmisibilita (T), gradien hidrolik (I) dan besarnya lebar aquier (L) diperlukan peta agihan tinggi muka air tanah bebas dan peta agihan kedalaman sumur. Berdasarka analisis Sistem Informasi Geografi terhadap data agihan sumur, kedalaman muka air tanah dan kedalaman sumur (Dinas Pertambangan Dan Energi Propinsi Jawa Tengah) dan cek lapangan) diperoleh peta agihan tinggi muka air tanah (gambar 3) dan peta agihan (gambar 4).

Berdasarkan peta agihan muka air tanah (gamber 3) dan peta agihan kedalaman air sumur (gambar 4) maka variasi besarnya koefisien transmisi-bilitas disajikan pada tabel 1. Rata-rata koefisien transmisibilitas air tanah bebas sebesar 290, $05 \mathrm{~m} 3 /$ hari 


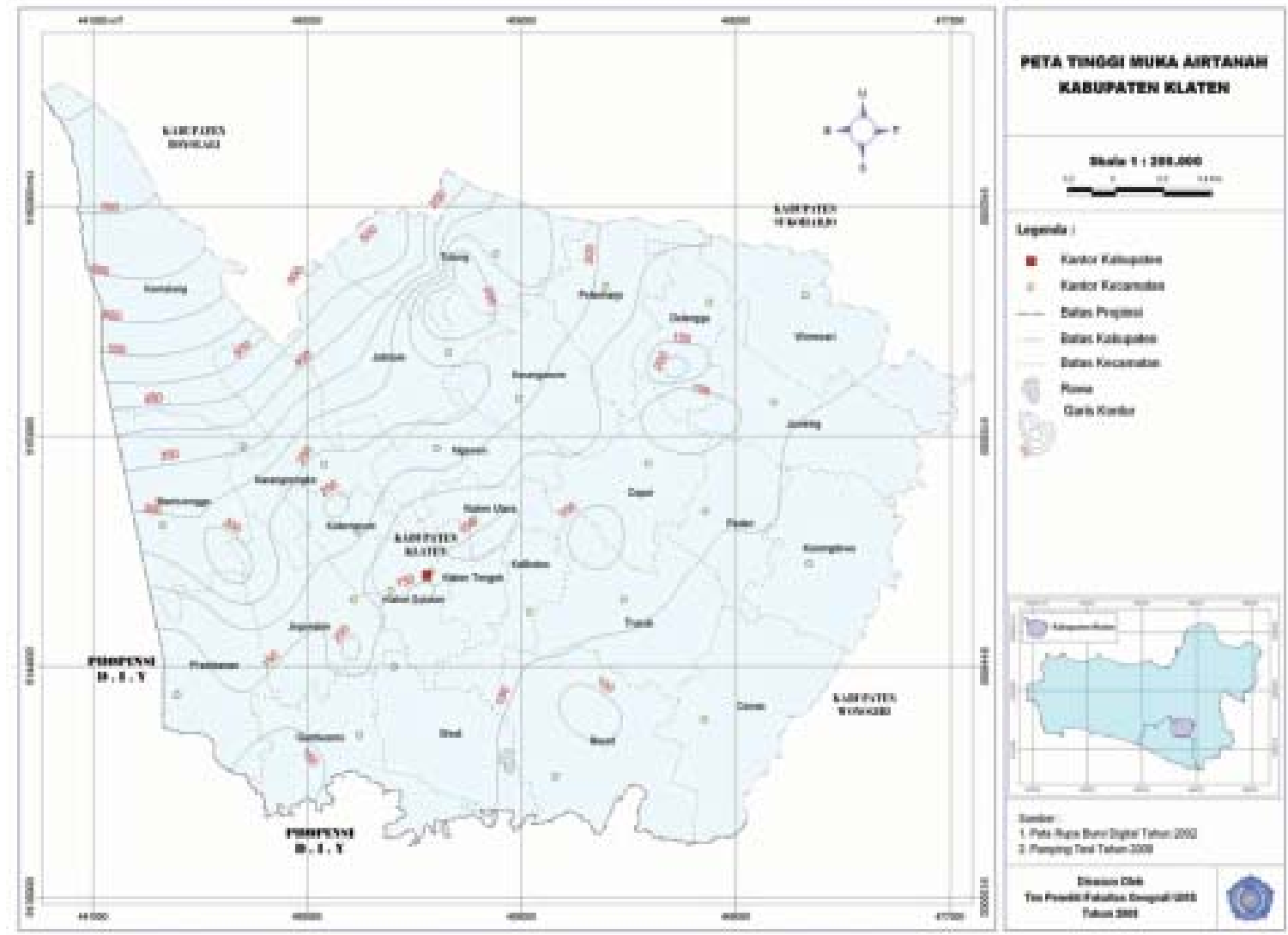

Sumber: Dinas pertambangan Dan Energi Propinsi Jawa Tengah (2003) dan Perhitungan GIS

Gambar 3. Peta Agihan Tinggi Muka air Tanah

Tabel 1. Perhitungan Nilai T Rata-rata Daerah Klaten

\begin{tabular}{|c|l|l|}
\hline No & \multicolumn{1}{|c|}{ Lokasi Pengukuran } & \multicolumn{1}{c|}{ T ( $\left.\mathbf{m}^{2} / \mathbf{h a r i}\right)$} \\
\hline 1 & Geneng, Prambanan & 151,44 \\
2 & Sanggrahan, Prambanan & 258,42 \\
3 & Wonoboyo, Jogonalan & 412,37 \\
4 & Gondangan, Jogonalan & 217,57 \\
5 & Wonosari, Trucuk & 477,90 \\
6 & Randusari, Prambanan & 222,59 \\
\hline & Rata-rata & 290,05 \\
\hline
\end{tabular}

Berdasarkan interpretasi peta agihan muka air tanah (gambar 3) variasi gradien hidrolik (I) dan rata rata lebar akuifer (L) disajikan pada tabel 2. 

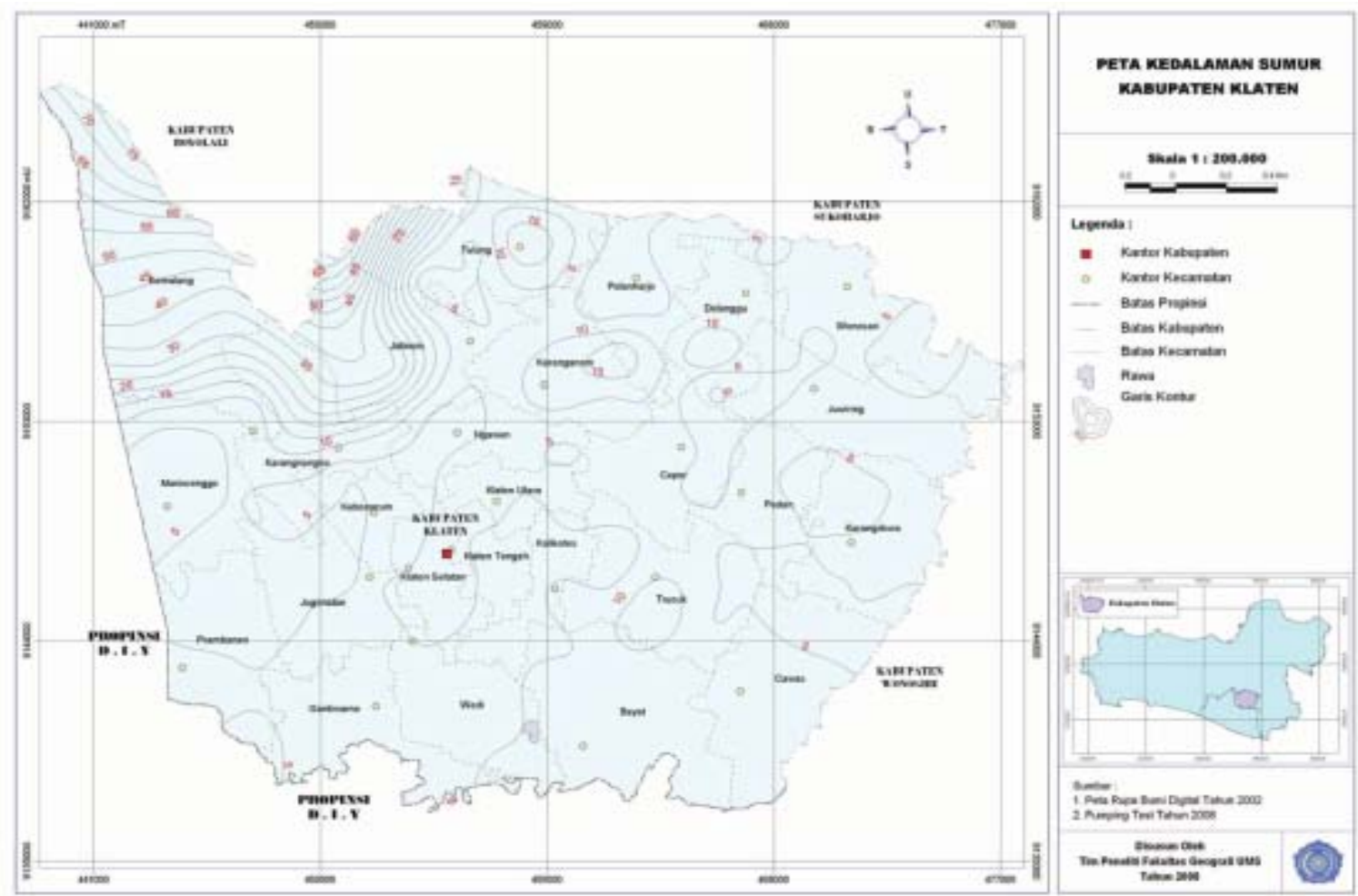

Sumber Dinas Pertambangan Dan Energi Propinsi Jawa Tengah (2003) dan perhitungan GIS

Gambar 4. Agihan Kedalaman Sumur pada Air Tanah Bebas

Tabel 2. Tabel Gradien Hidrolik Air Tanah Bebas pada Bentuklahan Dataran Fluviah Bawah Volkan Dan Kaki Volkan

\begin{tabular}{|c|c|c|c|c|}
\hline Klas Contur & $\begin{array}{c}\mathrm{A} \\
\left(\mathrm{K} \mathrm{m}^{2}\right)\end{array}$ & $\begin{array}{c}\mathrm{L} \\
(\mathrm{Km})\end{array}$ & $\mathrm{Wa}=\frac{A}{L}$ & $\mathrm{I}=\frac{C i}{W a}$ \\
\hline $250-200$ & 75,0 & 32,3 & 2,32 & 0,023 \\
\hline $200-150$ & 68,0 & 30,1 & 2,25 & 0,022 \\
\hline Rata-rata & & 31,2 & & 0,0225 \\
\hline
\end{tabular}

Berdasarkan tabel 2, diperoleh besar gradien hidrolik $(\mathrm{I})=0,0225$ dan rata-rata lebar akifer $(\mathrm{L})=31,2 \mathrm{Km}$. Debit air tanah bebas daerah Klaten yaitu:

$$
\begin{aligned}
\mathrm{Q}= & \mathrm{T} . \mathrm{I} . \mathrm{L}=31,2 \times 0,0225 \times 290,05= \\
& 203.615,1 \mathrm{~m}^{3} / \text { hari atau } 73.301 .436 \\
& \mathrm{~m} 3 / \text { tahun }
\end{aligned}
$$

\begin{abstract}
Air Tanah Tertekan
Air Tanah Tertekan; air tanah ini berada di bawah perlapisan batuan tidak tembus air atau impermiabel; dimana sumber air tanahnya berasal dari perlapisan batuan dibagian hulu. Untuk mengetahui debit air tanah tertekan digunakan rumus $\mathrm{Q}=\mathrm{TxIxL}$; perhitungan T,I dan L dikelompokkan ke dalam segmen wilayah air tanah tertekan (gambar 6).
\end{abstract}




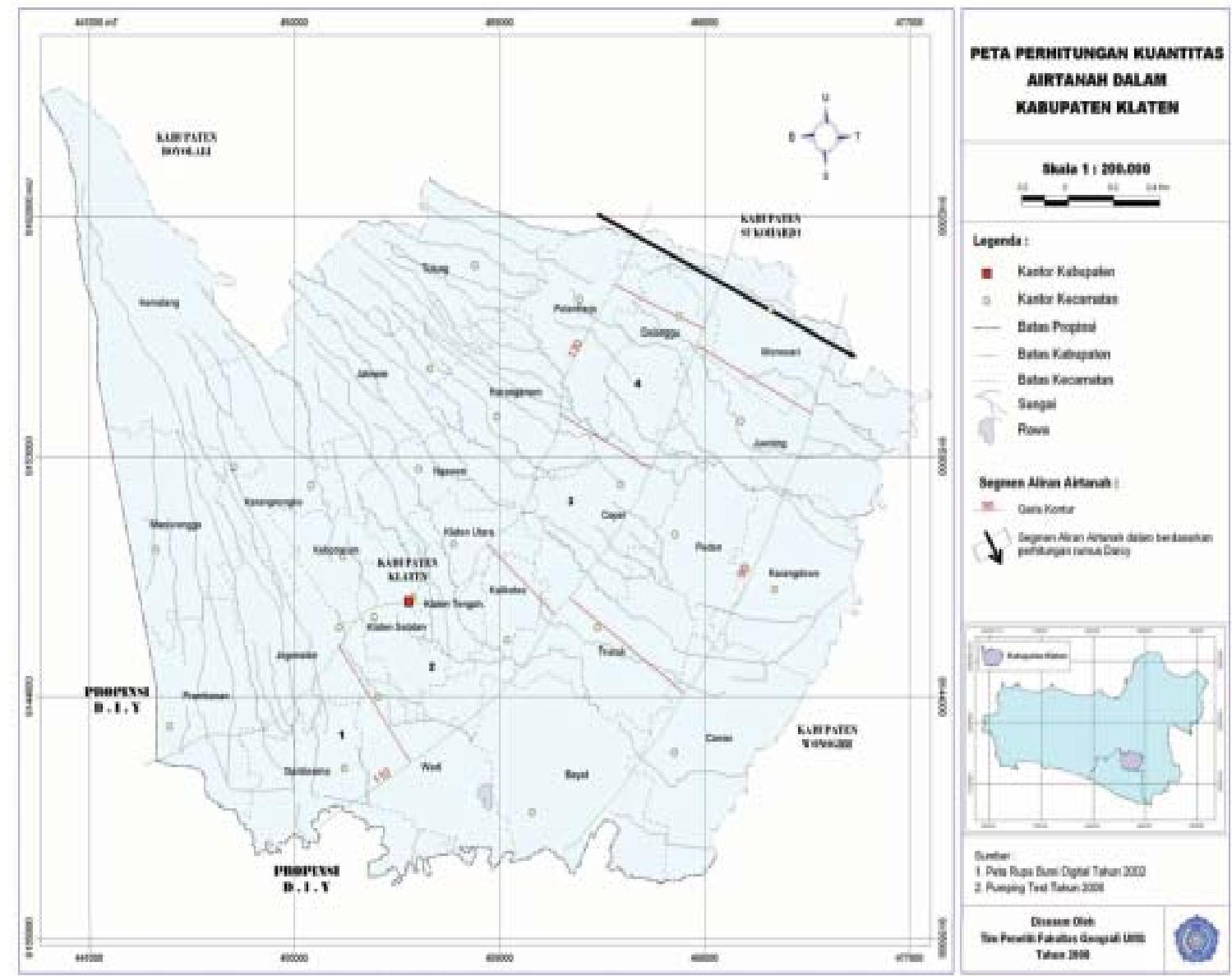

Sumber : Dinas Pertambangan Dan Energi Propinsi Jawa Tengah 2003

Gambar 6. Peta Segmen Wilayah Air Tanah Tertekan

Berdasarkan peta Segmen segmen wilayah air tanah tertekan (gambar 6) maka besarnya koeffisien tranmisibilitas (T), gradien hidrolik (I), lebar akuifer dan debir air tanah tertekan disetiap segmen yang mengalir di Catmet Area Klaten disajikan pada Tabel 3.

Tabel 3. Perhitungan Aliran Air tanah tertekan Wajar di CAT Klaten

\begin{tabular}{|c|c|c|c|c|}
\hline Segmen & $\mathrm{T}(\mathrm{m} 2 /$ hari $)$ & $\mathrm{I}$ & $\mathrm{L}(\mathrm{m})$ & $\mathrm{Q}(\mathrm{m} 3 /$ hari $)$ \\
\hline 1 & 722 & 0.005 & 4300 & 26714 \\
\hline 2 & 734 & 0.005 & 4000 & 28626 \\
\hline 3 & 791 & 0.006 & 3600 & 29899 \\
\hline 4 & 361 & 0.005 & 39.00 & 9566 \\
\hline Jumlah & & & & 94807 \\
\hline
\end{tabular}


Debit air tanah tertekan daerah Klaten sebesar $94.807 \mathrm{~m} 3 /$ hari atau $34.138 .520 \mathrm{~m} 3 /$ tahun.

\section{Mata Air}

Daerah Klaten terdapat 134 mata air, debit air dari mata air sebesar 153.062.784 $\mathrm{m} 3 /$ tahun atau $58.76 \%$, dari jumlah air tanah di daerah Klaten dan layak untuk air minum (Suharjo, 2005).

Berdasarkan hasil pengamatan langsung di lapangan terhadap singkapan batuan dan sumur gali penduduk, akuifer di daerah penelitian terdiri atas beberapa jenis batuan. Batuan yang menyusun akuifer dangkal umumnya sama yaitu pasir kasar hingga halus, kerikil, kerakal, tuf, dan batu pasir tuffan yang berasal dari endapan fluvial material Gunungapi Merapi. Ketebalan akuifer bervariasi mulai dari 2,00 $\mathrm{m}-23$ meter di bawah muka tanah setempat (m bmt).

Kedudukan air tanah antara $2,00-$ 23,00 meter ( $\mathrm{m} \mathrm{bmt)}$, tebal akuifer 5,00$23,00 \mathrm{~m}$. Pola kedalaman sumur gali, hampir selaras dengan satuan bentuklahan. Di satuan bentuklahan dataran fluvial bawah volkan muka air tanah antara 2,00 $\mathrm{m}-15.00 \mathrm{~m}$ (dangkal). Di satuan bentuklahan perbukitan structural daerah kecamatan Bayat keterdapatan muka air tanah lebih besar 15,00 m. (mbt); sedang di satuan bentuklahan kaki volkan dan lereng dan puncak volkan keterdapatan muka air tanah lebih dari $23 \mathrm{~m}$ (m mbt).

\section{Agihan Potensi Air Tanah di setiap Satuan Bentuklahan}

Debit air tanah daerah Klaten sebesar 260.502.740 m3/tahun atau 723 .618 .722 liter / hari. Besarnya debit airtanah tersebut debit aiar tanah bebas 73.301.436 m3/tahun, debit air tanah tertekan $34.138 .520 \mathrm{~m} 3 /$ tahun dan debit air tanah dari air mata air 153.062.784 m3/tahun.

\section{Karakteristik Fisika dan Kimia Airtanah}

Berdasarkan tabel 4, daya hantar listrik di bentuklahan dataran fluvial bawah volkan 359- $1360 \mathrm{mhos} / \mathrm{cm}$ atau tawar sampai dengan asin. Terdapatnya air asin (sampel 5,8 dan 13) tersebut akibat dampak gempa bumi tektonik, terjadi rekahan akuifer sehingga air asin yang merupakan air fosil menelusup ke dalam air sumur. Jalur air asin (connet water) berada di daerah peralihan antara bentuklahan asal Gunungapi Merapi dan bentuklahan asal struktural pegunungan Selatan Jawa (Suharjo, 2006).

Analsis kualitas air tanah untuk tujuan air minum juga dilakukan mendasarkan metode diagram pola stiff dan diagram paper.

\section{Analisis Diagram Stiff}

Salah satu cara untuk menganalisis kualitas airtanah di suatu daerah adalah dengan menggunakan diagram Stiff. Prinsip pembuatan diagram ini menggunakan ion dominan yang terlarut di dalam air. Hal yang perlu diperhatikan pada diagram sfiff adalah pada bentuk dan ukurannya. Bentuk diagram stiff menunjukkan sifat kimiawi air tanah yang didasarkan atas ion-ion dominan dalam airtanah didalamnya, sedangkan ukuran atau besar kecilnya diagram menunjukan besaran kadar ion-ion dominan tersebut. Hasil analisis data Laboratorium pada setiap lokasi sampel digunakan sebagai data dasar input untuk mengetahui dominasi distribusi kation dan anion pada setiap lokasi sampel Berdasarkan analisis menggunakan diagram stiff unsur dominan anion dan kation pada setiap titik sampel 


\begin{tabular}{|c|c|c|c|c|c|c|c|c|c|c|c|c|c|c|c|c|c|c|c|c|}
\hline & 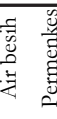 & 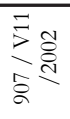 & & & ' & & \begin{tabular}{|l|}
$n$ \\
0 \\
1 \\
1 \\
0 \\
\end{tabular} & 3. & ' & 1 & & \& & ' & 吕 & $*$ & 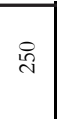 & 呙 & in & $m$ & \\
\hline ส & 崫 & $\vec{\Xi}$ & & & $\stackrel{\infty}{\underset{f}{f}}$ & & ج্ & $\because$ & if & 0 & 3 & 穴 & $\vec{i}$ & $\mid \begin{array}{l}\infty \\
\stackrel{\infty}{\sim}\end{array}$ & \begin{tabular}{|c|}
$\vec{y}$ \\
$\tilde{f}$ \\
$\tilde{f}$
\end{tabular} & $\ddot{m}$ & बे & ปี & 范 & \\
\hline$\vec{\lambda}$ & $\geqslant$ & $\stackrel{尺}{\Xi}$ & & & 命 & & 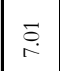 & $\stackrel{\circ}{\circ}$ & 号 & 0 & $\begin{array}{l}n \\
\infty \\
\infty\end{array}$ & 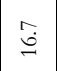 & $\begin{array}{l}n \\
\text { m. }\end{array}$ & $\stackrel{0}{m}$ & 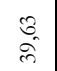 & ํำ & $\begin{array}{l}0 \\
\text { in }\end{array}$ & $\underset{\infty}{\stackrel{\infty}{\infty}}$ & 要 & \\
\hline ন & 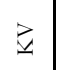 & $\stackrel{\Xi}{\Xi}$ & & & $\stackrel{\stackrel{n}{q}}{q}$ & & $\overrightarrow{\mid r}$ & $\stackrel{\overrightarrow{0}}{\circ}$ & $\stackrel{\check{\mathrm{N}}}{\mathrm{n}}$ & 0 & $\stackrel{9}{\exists}$ & $\underset{\text { i }}{\circ}$ & $\underset{i n}{i n}$ & \begin{tabular}{|l|}
$\hat{\infty}$ \\
$\stackrel{\infty}{\sim}$
\end{tabular} & 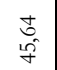 & $\overrightarrow{0}$ & $\begin{array}{l}0 \\
\text { in } \\
\end{array}$ & $\overrightarrow{\text { in }}$ & 要 & \\
\hline 2 & $\geqslant$ & $\stackrel{\Xi}{\Xi}$ & & & i & & 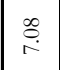 & $\mid \begin{array}{l}0 \\
0 \\
0\end{array}$ & $\stackrel{n}{n}$ & 0 & : & \begin{tabular}{|c|}
$\infty$ \\
$\stackrel{\sim}{i}$ \\
\end{tabular} & 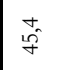 & $\overline{\text { ते }}$ & $\begin{array}{l}\vec{d} \\
\tilde{f} \\
f\end{array}$ & in & $\begin{array}{l}\circ \\
\dot{m}\end{array}$ & $\overrightarrow{\text { gr }}$ & | & \\
\hline$\stackrel{\infty}{\longrightarrow}$ & $\geqslant$ & $\stackrel{n}{\Xi}$ & & & 字 & & 节 & ণ্ণি & $\stackrel{\leftrightarrow}{g}$ & 0 & ชુ & \begin{tabular}{|l|} 
\\
$\stackrel{n}{y}$ \\
\end{tabular} & $\mid \begin{array}{l}\dot{\sigma} \\
\dot{\sigma}\end{array}$ & $\overrightarrow{\mathrm{i}}$ & $\left|\begin{array}{l}\infty \\
\infty \\
\& \\
\sigma \\
\sigma\end{array}\right|$ & $\underset{త ్}{+}$ & $\hat{\mathrm{s}}$ & & 号 & \\
\hline$=$ & $\geqslant$ & $\stackrel{+}{\Xi}$ & & & हें & & $\stackrel{\Re}{\stackrel{2}{r}}$ & $\because$ & 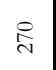 & 0 & 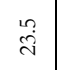 & \begin{tabular}{|l|}
$n$ \\
$\infty$ \\
$\infty$ \\
$\rightarrow$
\end{tabular} & 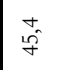 & ભ્ల & 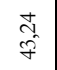 & $\stackrel{\circ}{\circ}$ & $\hat{\mathrm{s}}$ & in & 苛 & \\
\hline$\stackrel{\circ}{\simeq}$ & 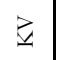 & $\tilde{\Xi}$ & & & $\frac{5}{6}$ & & $\begin{array}{l}\infty \\
\infty \\
0\end{array}$ & $\mid \begin{array}{c} \pm \\
\end{array}$ & 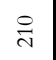 & 0 & $\stackrel{n}{\stackrel{n}{n}}$ & $\stackrel{+}{\stackrel{ \pm}{\leftrightarrows}}$ & $\stackrel{2}{i n}$ & 四 & $\begin{array}{l}\text { 表 } \\
\text { f }\end{array}$ & $\ddot{g}$ & वे & in & | & \\
\hline 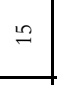 & 畕 & $\mathbb{\Xi}$ & & & 品 & & \begin{tabular}{|l|} 
\\
$\infty$ \\
0 \\
0
\end{tabular} & $\stackrel{ \pm}{0}$ & $\ddot{d}$ & 0 & $\stackrel{\overrightarrow{\dot{v}}}{\vec{j}}$ & $\stackrel{\imath}{\check{z}}$ & $\overrightarrow{80}$ & $\stackrel{\infty}{\stackrel{\infty}{+}}$ & $\mid \begin{array}{c}g^{\infty} \\
\infty \\
\infty \\
\infty\end{array}$ & $\approx$ & $\begin{array}{l}\infty \\
\infty \\
\stackrel{n}{n}\end{array}$ & đ̇ं & हे. & \\
\hline \pm & 啹 & $\bar{\Xi}$ & & & 守 & & 号 & $\stackrel{\circ}{\circ}$ & $\stackrel{\gtrless}{2}$ & 0 & $\stackrel{n}{2}$ & 焉 & ¿े & ลे & \begin{tabular}{|l|} 
\\
$\infty$ \\
$\infty$ \\
\end{tabular} & $\stackrel{\leftrightarrow}{i}$ & 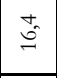 & ${ }_{\infty}$ & శ్ & \\
\hline 9 & 总 & $\underset{\Xi}{\Xi}$ & & & 앙 & & \begin{tabular}{|l|l|} 
\\
0 \\
0 \\
0
\end{tabular} & 官 & $\stackrel{\text { 学 }}{\text { d }}$ & 0 & $\vec{\Xi}$ & $\stackrel{8}{\stackrel{9}{\perp}}$ & 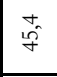 & $\tilde{\widetilde{c}}$ & 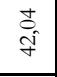 & $\stackrel{\circ}{\circ}$ & \begin{tabular}{|c}
$n$ \\
in \\
in
\end{tabular} & ले & \begin{tabular}{|l}
3 \\
0 \\
0
\end{tabular} & \\
\hline$\simeq$ & $\begin{array}{l}\text { 总 } \\
\end{array}$ & 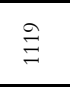 & & & 字 & & \begin{tabular}{|c|}
1 \\
0 \\
1 \\
1 \\
0 \\
\end{tabular} & 3 & $\stackrel{8}{\circ}$ & $\dot{0}$ & 庆 & \&્ત & $\mid \begin{array}{c}t \\
\dot{q}\end{array}$ & $\widetilde{\approx}$ & 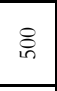 & $\begin{array}{l}\infty \\
\infty \\
i\end{array}$ & : & : & in & \\
\hline$=$ & 总 & $\stackrel{\infty}{\exists}$ & & & 守 & & 空 & $\overrightarrow{\tilde{g}}$ & $\stackrel{\infty}{\sim}$ & $\dot{0}$ & $\underset{ \pm}{+}$ & $\stackrel{?}{ \pm}$ & $\underset{\text { in }}{\mathrm{in}}$ & 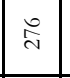 & \begin{tabular}{|l|}
8 \\
8 \\
0 \\
$m$
\end{tabular} & ָु & \begin{tabular}{|l|}
$n^{\infty}$ \\
$\infty$ \\
$\infty$
\end{tabular} & 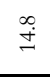 & $\begin{array}{l}0 \\
0 \\
0\end{array}$ & \\
\hline 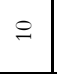 & 崫 & $\Xi$ & & & 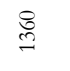 & & वิ & 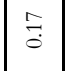 & $\stackrel{\sim}{\circ}$ & $\circ$ & $\begin{array}{l}n \\
\tilde{c} \\
\tilde{c}\end{array}$ & $\overrightarrow{\dot{\omega}}$ & \begin{tabular}{|l}
2 \\
30 \\
30
\end{tabular} & ঃ & 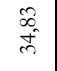 & $\stackrel{+}{+}$ & 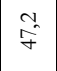 & : & \begin{tabular}{|l}
$\infty$ \\
\multirow{8}{0}{} \\
0
\end{tabular} & \\
\hline$a$ & 啹 & 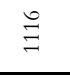 & & & in & & $\begin{array}{l}8 \\
8 \\
0\end{array}$ & $\stackrel{ \pm}{\circ}$ & శ్లి & 0 & $\stackrel{q}{q}$ & 心 & ${ }^{2}{ }^{2}$ & 号 & \begin{tabular}{|l|}
8 \\
0 \\
0 \\
$\infty$
\end{tabular} & $\ddot{n}$ & ${ }_{\infty}^{\infty}$ & $\stackrel{g}{q}$ & 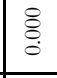 & \\
\hline$\infty$ & 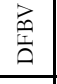 & $\stackrel{n}{\Xi}$ & & & $\stackrel{\text { ॥̊ }}{\mathrm{N}}$ & & $\stackrel{n}{\stackrel{n}{r}}$ & $\because$ & $\stackrel{\substack{n \\
c}}{a}$ & 0 & $\begin{array}{l}n \\
\text { 心్ల }\end{array}$ & $\stackrel{0}{\dot{\oplus}}$ & $\mid \begin{array}{c}+ \\
\stackrel{\sigma}{\sigma}\end{array}$ & $\bar{\lambda}$ & $\begin{array}{l}8 \\
8 \\
0 \\
c\end{array}$ & $\stackrel{q}{\dot{f}}$ & 今. & : & 蒫 & \\
\hline r & 尊 & $\stackrel{ \pm}{\Xi}$ & & & ğ & & $\stackrel{n}{?}$ & $\stackrel{?}{\circ}$ & 巟 & 0 & $\stackrel{t}{\circ}$ & 光 & है & 系 & $\begin{array}{l}0 \\
\substack{0 \\
\vdots \\
\pm}\end{array}$ & $\stackrel{n}{\subseteq}$ & $\vec{f}$ & $\therefore$ & 音 & \\
\hline 0 & 啹 & $\stackrel{\Xi}{\exists}$ & & & $\stackrel{\circ}{\circ}$ & & \begin{tabular}{|l}
$\stackrel{2}{2}$ \\
$\stackrel{2}{r}$
\end{tabular} & $\stackrel{\infty}{\circ}$ & 怘 & 8 & $\begin{array}{l}n \\
\mathfrak{d} \\
\end{array}$ & \begin{tabular}{|c|} 
\\
in \\
\end{tabular} & $\begin{array}{l}a \\
\infty \\
\infty \\
\end{array}$ & \& & \begin{tabular}{l}
$u$ \\
\multirow{z}{f}{} \\
$\tilde{f}$
\end{tabular} & $\stackrel{\sim}{~}$ & \begin{tabular}{|l|}
8 \\
8 \\
$i n$
\end{tabular} & $\stackrel{\circ}{\longrightarrow}$ & 兽 & \\
\hline in & 兽 & $\cong$ & & & 怘 & & 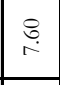 & ণ্ণী & ષ્ণి & $\stackrel{8}{8}$ & 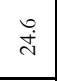 & \begin{tabular}{|l} 
\\
$\dot{+}$ \\
\end{tabular} & $\begin{array}{l}0 \\
\stackrel{I}{\Xi}\end{array}$ & f & \begin{tabular}{|l|} 
\\
t. \\
in
\end{tabular} & $\stackrel{m}{~}$ & $\mid \begin{array}{l}0 \\
\dot{2} \\
i\end{array}$ & t. & : & \\
\hline+ & 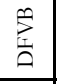 & $\Xi$ & & & \& & & 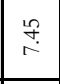 & $=$ & $\stackrel{\mathrm{a}}{\mathrm{i}}$ & $\stackrel{8}{8}$ & 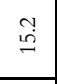 & $\overrightarrow{\vec{b}}$ & $\stackrel{\circ}{i}$ & $\stackrel{\circ}{\circ}$ & $\begin{array}{c}\hat{心} \\
\mathrm{~m}^{2}\end{array}$ & 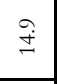 & $\begin{array}{l}n \\
n \\
i n\end{array}$ & $\infty$ & $\mid \begin{array}{l}\infty \\
\vdots \\
0 \\
0\end{array}$ & छ் \\
\hline$m$ & 总 & 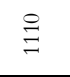 & & & in & & \begin{tabular}{|l|}
8 \\
$\infty$ \\
$\infty$
\end{tabular} & $\stackrel{?}{\circ}$ & $\stackrel{\circ}{\circ}$ & $\stackrel{8}{0}$ & $\begin{array}{c}+ \\
\stackrel{\infty}{\infty}\end{array}$ & $\stackrel{\odot}{\vec{i}}$ & ${ }^{2}$ & $\stackrel{\overbrace{}}{\curvearrowright}$ & $\begin{array}{l}\text { for } \\
\text { df } \\
\tilde{e}\end{array}$ & $\stackrel{\stackrel{i}{i}}{ }$ & $\vec{F}$ & $\mid \begin{array}{c}\infty \\
i \\
i\end{array}$ & $\stackrel{2}{0}$ & है \\
\hline$\sim$ & 总 & $\stackrel{g}{g}$ & & & 哭 & & $\begin{array}{l}\vec{t} \\
\stackrel{\infty}{0}\end{array}$ & $\stackrel{\infty}{\circ}$ & సิ & 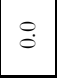 & ठे & ה & \begin{tabular}{|l|l}
$\infty$ \\
sid
\end{tabular} & ঃ & \begin{tabular}{|l}
7 \\
$\infty$ \\
$\infty$ \\
$\infty$ \\
$\infty$
\end{tabular} & $\begin{array}{l}\infty \\
i \\
i\end{array}$ & बे & $\therefore$ & $\bar{\Xi}$ & $\begin{array}{l}\overrightarrow{0} \\
\text { ते }\end{array}$ \\
\hline- & 总 & $\stackrel{\infty}{=}$ & & & 导 & & 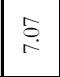 & $\overrightarrow{\stackrel{\Xi}{\circ}}$ & $\stackrel{8}{-}$ & $\stackrel{8}{\circ}$ & 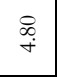 & $\begin{array}{l}+ \\
\infty \\
\stackrel{\infty}{-}\end{array}$ & $\begin{array}{l}+ \\
\dot{\sigma} \\
\dot{q}\end{array}$ & 号 & $\begin{array}{l}\mathcal{f} \\
\text { ff } \\
\tilde{e}\end{array}$ & 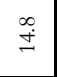 & $\begin{array}{l}\text { q } \\
\text { fे }\end{array}$ & $\begin{array}{l}\infty \\
\infty \\
\infty \\
\infty\end{array}$ & ब్ర & $\stackrel{\pi}{\cong}$ \\
\hline \multirow[b]{2}{*}{ 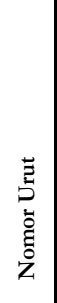 } & \multirow[b]{2}{*}{ 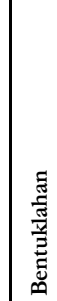 } & \multirow{2}{*}{ 园 } & 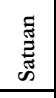 & & $\begin{array}{l}\text { के } \\
\text { हैं }\end{array}$ & & , & $\underset{\Xi}{\stackrel{10}{g}}$ & $\underset{⿱ D D}{\stackrel{D}{E}}$ & $\begin{array}{l}\stackrel{+}{b 0} \\
\Xi \\
\Xi\end{array}$ & $\underset{⿱ D}{g}$ & \begin{tabular}{|l|}
$\stackrel{H}{b 0}$ \\
$\Xi$
\end{tabular} & 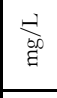 & 㔖 & \begin{tabular}{|l|}
$\stackrel{1}{b 0}$ \\
$\Xi$ \\
$\Xi$
\end{tabular} & $\underset{b D}{\stackrel{D}{g}}$ & 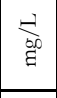 & $\stackrel{+}{\stackrel{0}{0}}$ & $\underset{g}{\stackrel{5}{00}}$ & $\sum$ \\
\hline & & & 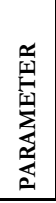 & 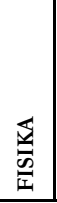 & 吾 & $\begin{array}{l}\mathbb{3} \\
\text { 音 }\end{array}$ & 表 & 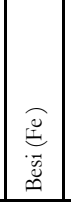 & 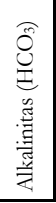 & 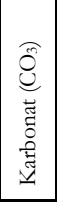 & 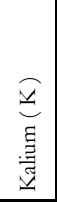 & 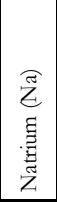 & 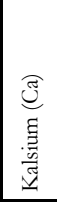 & 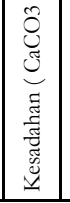 & 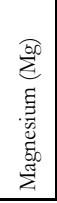 & 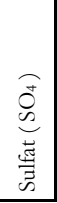 & 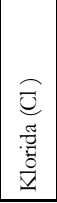 & 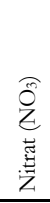 & 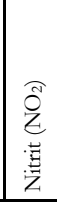 & 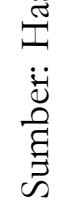 \\
\hline
\end{tabular}




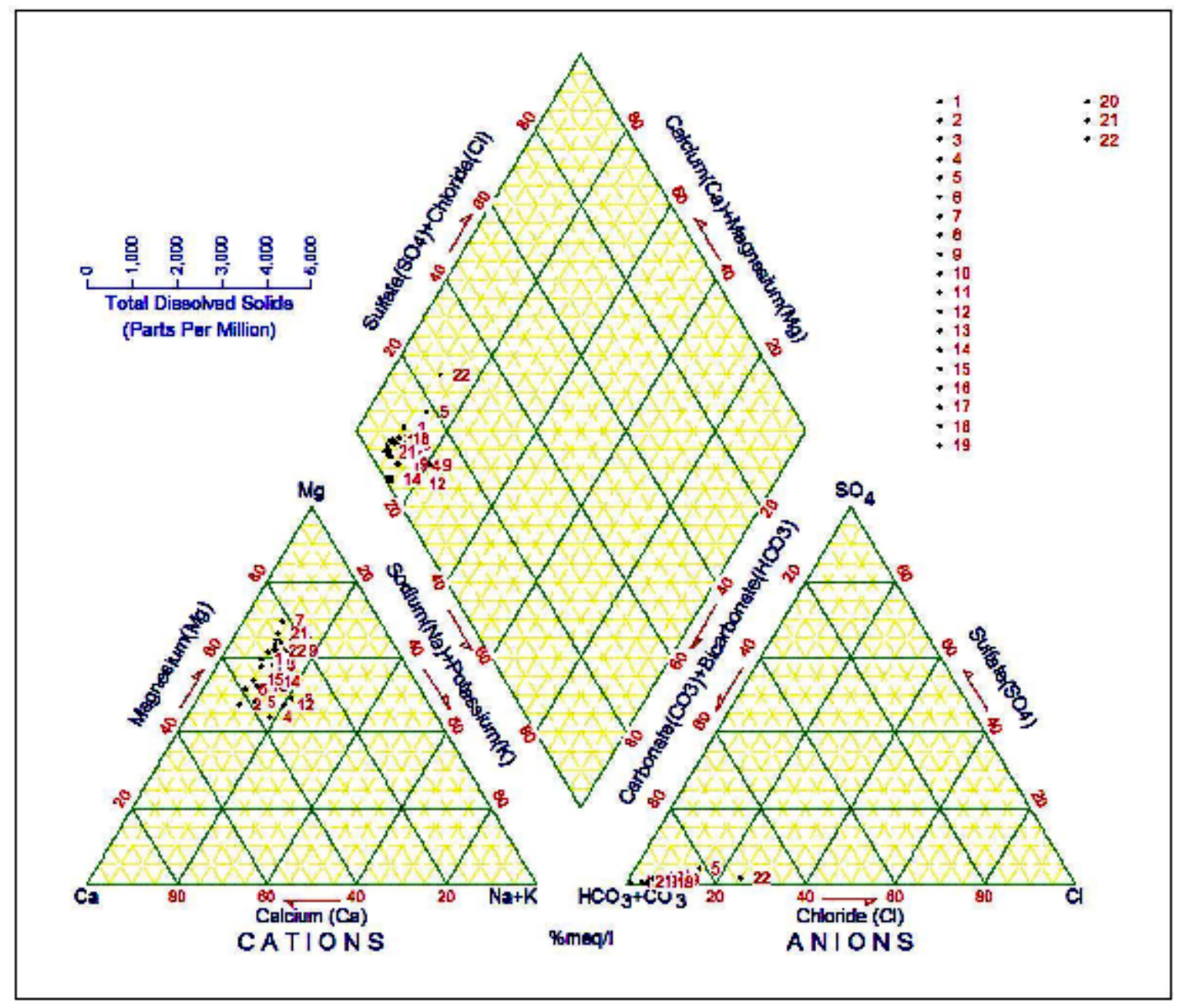

Gambar 7. Diagram Piper untuk Menunjukan Distribusi

Masing-masing Unsur Setiap Titik Sampel

adalah unsur Magnesium $\left(\mathrm{Mg}^{+2}\right)$ pada kation dan unsur Bikarbonat ( $\mathrm{HCO}_{3}$ ) pada anion. Daerah penelitian kualitas airnya menunjukan pola seragam pada setiap unsur mayor (kation dan anion) pada masing - masing titik sampel,hal ini ditunjukkan oleh bentuk diagram stiff. Kecenderungan unsur kation lebih banyak dijumpai pada lokasi sampel di daerah Kecamatan Wonosari (dengan dominasi unsur $\mathrm{Mg}$ ) sedangkan kecenderungan unsur anion lebih tinggi terdapat pada daerah Kecamatan Manisrenggo (dengan dominasi unsur $\mathrm{HCO}+\mathrm{CO}_{3}$ ). Distribusi diagram stiff pada måsing- $\stackrel{3}{\text { masing lokasi }}$ di setiap satuan bentuklahan ditunjukkan pada peta distribusi diagram stiff seperti terlihat pada gambar 8 .

Untuk lebih memperjelas dominasi kualitas air di daerah penelitian maka digunakan juga diagram piper. Diagram Piper merupakan diagram yang digunakan untuk menentukan unsur dominan pada setiap lokasi penelitian. Variabel yang digunakan adalah unsur-unsur mayor dari kation ( $\mathrm{Ca}, \mathrm{Na}, \mathrm{K}, \mathrm{Mg}$ ) dan anion ( $\mathrm{SO}$, $\mathrm{HCO}$ dan $\mathrm{Cl}$ ) ditambah dengan TDS Sै. Ploting kation dan anion pada setiap sampel menunjukkan bahwa pada daerah pene- 


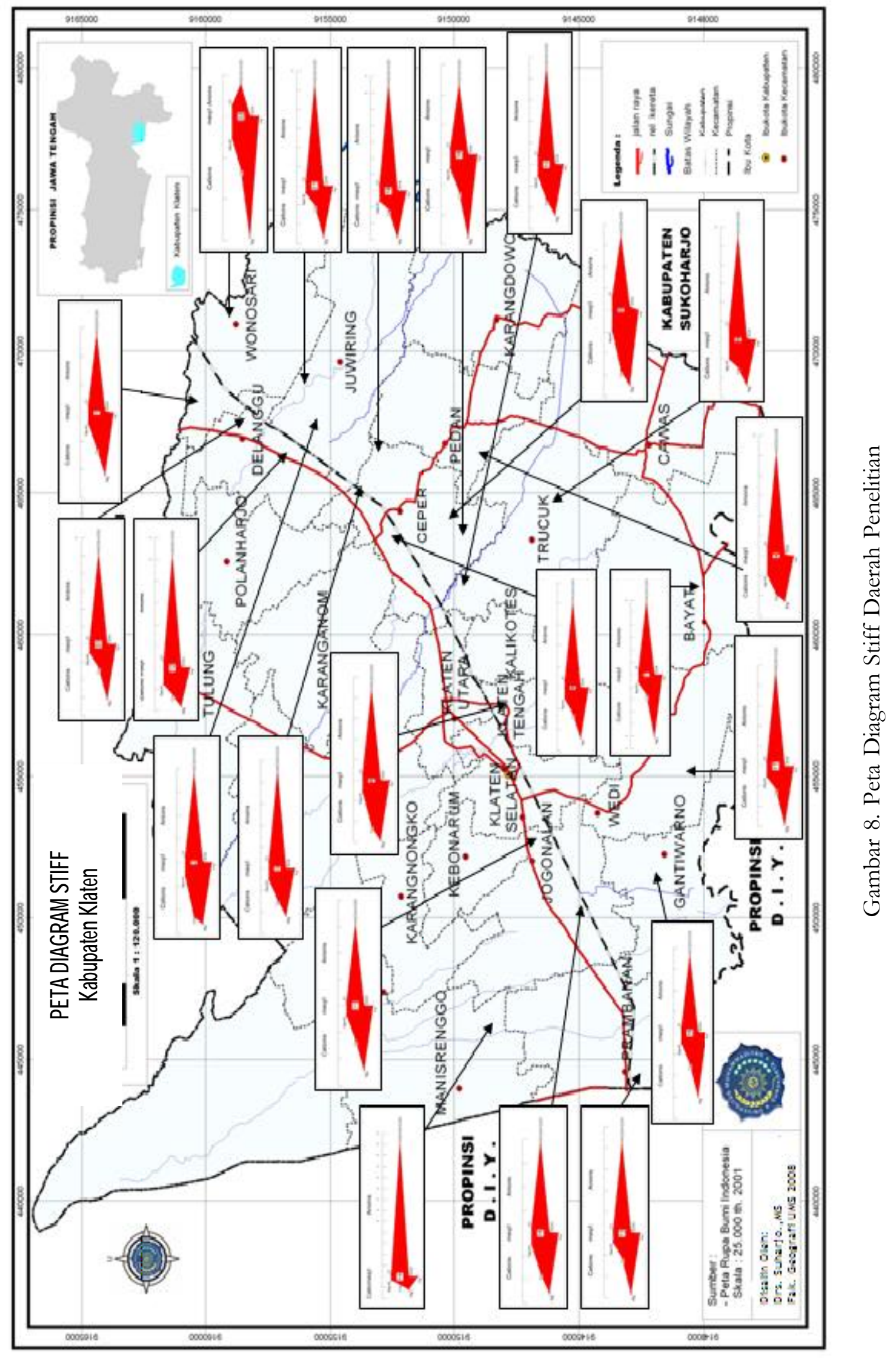


litian sebagian besar kualitas air didominasi oleh unsur $\mathrm{Mg}$, $\mathrm{SO}+\mathrm{Cl}$ dan $\mathrm{HCO}+\mathrm{CO}$. Distribusi masing ${ }^{4}-$ masing unsur pada $^{3}$ setiap titik sampel ditunjukkan pada gambar diagram piper seperti terlihat pada gambar 7.

\section{KESIMPULAN DAN SARAN}

\section{Kesimpulan}

1. Berdasarkan bentuklahan, daerah Klaten terbagi dalam empat satuan bentuklahan, yaitu lereng dan puncak volkan, kaki volkan, dataran fluvial bawah volkan, dan satuan asal struktural.

2. Potensi air tanah dinilai atas dasar jumlah air tanah dan kualitas air tanah. Jumlah air taah daerah Klaten $260.502 .740 \mathrm{~m}^{3} /$ tahun atau 723 .618.722 liter / hari. Jum-lah tersebut berasal dari Air tanah bebas 73.301.436 $\mathrm{m}^{3} /$ tahun, air tanah tertekan $34.138 .520 \mathrm{~m} /$ tahun dan air tanah dari mata air $153.062 .784 \mathrm{~m}^{3} /$ tahun. Kualitas air tanah dangkal daerah Klaten berada dibawah standar baku mutu air minum yang ditetapkan oleh PERMENKES No. 907/MENKES/ SK/VII/2002 atau layak untuk air minum.

3. Agihan potensi air tanah tinggi berada di bentuklahan kaki volkan, potensi airtanah sedang di bentuklahan dataran fluvial bawah volkan dan potensi air tanah rendah berada di lereng volkan dan perbukitan struktural daerah Bayat.

4. Gempa bumi tektonik berdampak pada potensi air tanah di bentuklahan dataran fluvial bawah volkan dan perbukitan struktural derah kecamatan Bayat, Wonosari dan Gantiwarno. Sebagian sumur daerah tersebut air tanah asin dan terjadi degradasi lahan (rekahan, amblesan) sehingga merubah struktur akuifer.

\section{Saran}

1. Berdasarkan kajian potensi air tanah daerah Klaten, maka daerah prospek untuk dikembangkan pemanfaat air tanahnya adalah terletak di wilayah potensi sedang - tinggi yaitu di bentuklahan kaki volkan.

2. Perlu dilakukan pemantauan kualitas air tanah secara berkala dengan unsur yang diuji secara lengkap sesuai dengan unsur pada standar air minum, ditambah dengan unsur logam dan bakteri. Perhatian utama adalah pemantauan unsur Nitrit dan Nitrat.

\section{UCAPAN TERIMA KASIH}

Ucapan terima kasih kepada DP2M Ditjen Dikti yang telah membiayai program penelitian Hibah Bersaing Tahun Pertama tahun anggaran 2008.

\section{DAFTAR PUSTAKA}

Alif Noor Anna; dkk, 2006. Analisis Karakteristik Parameter bidrologi Akibat Alib Fungsi lahan Di Daerah Sukoharjo Melalui Citra Landsat Tabun 1997 dengan Tabun 2002. Fakultas Geografi Universitas Muhammadiyah Surakarta

Engelen, G.B; F. Klosterman, 1996. Hydrological System Analysis Method and Applications. Kluwer Academic Publisher. London. 
Imam Hardjono. 2006. "Hirarki Gempa Bumi dan Tsunami (Aceh, Nias, Bantul, Pangandaran, dan Selat Sunda”. Forum Geografi, Vol. 20, No. 2, Desember 2006. Hlm 135-141.

Muhammad Aqil, Yomota Atsshi, Abi Prabowo, 2006. Model Pengelolaan Sumberdaya Air di Jepang. http://io.ppi-jepang.org/article.php?id=89.

Retno Woro Kaeksi, dkk, 2005. Agihan Kekritisan Sumber Daya Air Daerah Sukoharjo Jawa Tengah. Direktorat Pengembangan Penelitian dan Pengabdian pada Masyarakat Direktorat Jendral Pendidikan Tinggi Departemen Pendidikan Nasional.

Soenarno, 2005. Kebijakan Pengelolaan Sumber Daya Air dan Privatisasi atas Air. Makalah Proseding Seminar Nasional. Fak. Geografi UMS

Suharjo; dkk, 2004. Perubaban Penggunaan Lahan dan Pengarubnya Terbadap Kualitas Air Tanah di Daerah Sukoharjo sebagai Penyangga Kota. Direktorat Pembinaan Penelitian dan Pengabdian pada Masyarakat Direktorat Jenderal Pendidikan Nasional. Departemen Pendidikan Nasional.

Suharjo; dkk, 2005. Studi dan Pemetaan Sumber Air di Kabupaten Klaten. Badan Perencanaan Pengembangan Daerah ( BAPPEDA) Kabupaten Klaten.

Suharjo, dkk, 2006. Analisis Proses Geomorfologi Melalui GIS Untuk Pengelolaan Lahan Pertanian Daerah Kabupaten Klaten Jawa Tengah. Fak. Geografi UMS.

Suharjo, 2006. Proses Geomorfologi Daerah Solo Jawa Tengah. Penelitian Fundamental, Direktorat Pembinaan Penelitian dan Pengabdian pada Masyarakat Direktorat Jenderal Pendidikan Nasional. Departemen Pendidikan Nasional.

- 2003. Kajian Zonasi Konfigurasi Dan Tata Guna Air Bawah Tanab Pada Cekungan Semarang- Demak, Subah Dan Karanganyar -Boyolali Propinsi Jawa Tengah. Dinas Pertambangan dan Energi Propinsi Jawa Tengah

Suprihanto Notodarmojo, 2005. Pencemaran Tanah dan Air Tanah. ITB, Jl.Ganesa 10 Bandung.

Sutikno. 2007. "Earthquake Disaster of Yogyakarta and Central Java, and Disaster Reduction, Indonesia". Forum Geografi, Vol. 21, No. 1, Juli 2007. Hlm 1-16.

Tood. David Keith, 1959. Grounwater Hydrology. New York John Wely and Sons.

Totok Gunawan, 2003. Pemanfaatan Teknik Penginderaan Jauh Untuk Pemantauan dan Evaluasi pengelolaan Daerah Aliran Sungai Solo. Forum Geografi .Vol. 17 No. 2, Desember 2003.

Verstappen, H.Th, 1983. Applied Geomorphology. Geomorphological Surveys for Environmental Development New York, El sevier. 